\title{
Emerging Preservation Techniques for Controlling Spoilage and Pathogenic Microorganisms in Fruit Juices
}

\author{
Kamal Rai Aneja, ${ }^{1}$ Romika Dhiman, ${ }^{2}$ Neeraj Kumar Aggarwal, ${ }^{2}$ and Ashish Aneja ${ }^{3}$ \\ ${ }^{1}$ Vaidyanath Research, Training and Diagnostic Centre, Kurukshetra 136118, India \\ ${ }^{2}$ Department of Microbiology, Kurukshetra University, Kurukshetra 136119, India \\ ${ }^{3}$ University Health Centre, Kurukshetra University, Kurukshetra 136119, India
}

Correspondence should be addressed to Romika Dhiman; romikadhiman@gmail.com

Received 20 January 2014; Accepted 20 June 2014; Published 22 September 2014

Academic Editor: Hugh W. Morgan

Copyright (C) 2014 Kamal Rai Aneja et al. This is an open access article distributed under the Creative Commons Attribution License, which permits unrestricted use, distribution, and reproduction in any medium, provided the original work is properly cited.

\begin{abstract}
Fruit juices are important commodities in the global market providing vast possibilities for new value added products to meet consumer demand for convenience, nutrition, and health. Fruit juices are spoiled primarily due to proliferation of acid tolerant and osmophilic microflora. There is also risk of food borne microbial infections which is associated with the consumption of fruit juices. In order to reduce the incidence of outbreaks, fruit juices are preserved by various techniques. Thermal pasteurization is used commercially by fruit juice industries for the preservation of fruit juices but results in losses of essential nutrients and changes in physicochemical and organoleptic properties. Nonthermal pasteurization methods such as high hydrostatic pressure, pulsed electric field, and ultrasound and irradiations have also been employed in fruit juices to overcome the negative effects of thermal pasteurization. Some of these techniques have already been commercialized. Some are still in research or pilot scale. Apart from these emerging techniques, preservatives from natural sources have also shown considerable promise for use in some food products. In this review article, spoilage, pathogenic microflora, and food borne outbreaks associated with fruit juices of last two decades are given in one section. In other sections various prevention methods to control the growth of spoilage and pathogenic microflora to increase the shelf life of fruit juices are discussed.
\end{abstract}

\section{Introduction}

Consumer demand for nutritious foods such as fresh cut fruits and unpasteurized fruit juices has increased in the last decades owing to their low content of sodium, cholesterol and fat and high concentration of vitamin C, polyphenols, and antioxidants that play important role in the prevention of heart diseases, cancer, and diabetes [1-4]. Juice is defined as unfermented but fermentable juice, intended for direct consumption, obtained by the mechanical process from sound, ripe fruits, and preserved exclusively by physical means. The addition of sugars or acids can be permitted but must be endorsed in the individual standard [5-7] Increased consumption of fruit juices has direct influence on economy in positive way but in negative way also when food borne disease outbreaks and spoilage problems occur [8]. Juices have become frequent vehicle for transmitting pathogens such as enterohaemorrhagic Escherichia coli O157, Salmonella, and Cryptosporidium [9]. Several emerging spoilage microorganisms also have great concern in fruit juice industry; for example, Alicyclobacillus acidoterrestris has been isolated from several juices and juice products with reported occurrence between $14.7 \%$ and 18.3\%. Propionibacterium cyclohexanicum and heat resistant species of mycelial fungi such as Byssochlamys fulva, $B$. nivea, and Neosartorya fischeri and species of Talaromyces have also been reported to spoil fruit juices [10-13]. There is tremendous increase in the food borne disease outbreaks associated with the consumption of fruit juices [14].

Keeping in view the threat challenge posed by spoilage and pathogenic microorganisms to both the fruit juice industry and public health authorities, several guidelines have 
been published by national food standard agencies, such as HACCP and FDA, to control or reduce the incidence of food borne disease outbreaks or spoilage [8]. For prevention of these microorganisms in fruit juices, thermal treatment is effective method for microbial inactivation but it may produce some undesirable effects on foods such as loss of nutrients and reduction of fresh like flavor $[15,16]$. New technologies such as high hydrostatic pressure (HHP), high pressure homogenization (HPH), pulsed electric field (PEF), ultrasound, and irradiations have been developed to maintain nutritional and sensory quality of fruit juices [17, 18].

Chemical preservatives, such as sodium benzoate and potassium sorbate, are commonly used in fruit juices and beverages to extend their shelf life [11]. However, consumer demand for fresh and safe foods without chemically synthesized preservatives leads to increase the interest in use of food preservatives from natural sources [19]. Natural preservatives such as bacteriocins, organic acids, essential oils, and phenolic compounds have been used in some food products $[19,20]$.

\section{Microorganisms Involved in Spoilage}

Change in the appearance, smell or taste of a food that makes it unacceptable to the consumer is called food spoilage [21]. Spoilage of fruit and vegetable juices is primarily owing to the proliferation of their natural acid tolerant and osmophilic microflora [22]. Fresh fruit juices are more susceptible to spoilage because fluid contents are in touch with air and microorganisms from the environment during the time of handling [4]. Yeasts, heat sensitive moulds, and lactic acid bacteria are indicator for the quality of raw materials. Heat resistant fungi and other spore forming bacteria such as Clostridium pasteurianum and Bacillus coagulans are used as targets for fruit juice pasteurization processes [8].

\section{Yeasts}

Yeasts have the ability to grow at low $\mathrm{pH}$, high sugar concentration, and low water activity. Fruit juices are generally rich in simple carbohydrates and complex nitrogen sources and hence are ideal substrates for yeasts [22]. Over 110 species of yeasts have been reported to be associated with food and food products [23] and are dominating contaminants in fruit juices ranging from 1.0 to $6.83 \log 10 \mathrm{cfu} / \mathrm{mL}$ [24]. The presence of yeasts in fruit juices may result from failures in fruit juice pasteurization and failure in sanitation practices [8]. Spoilage by yeasts in fruit juices is characterized by formation of $\mathrm{CO}_{2}$ and alcohol. Yeasts may also produce turbidity, flocculation, pellicles, and clumping. Yeasts also produced pectinesterases which degrade pectin causing spoilage, organic acids, and acetaldehyde, which contribute for a "fermented flavor," may also be formed $[6,25]$.

Pichia, Candida, Saccharomyces, and Rhodotorula are the genera mainly responsible for the spoilage of fruit juices; species frequently isolated are Pichia membranifaciens, Candida maltosa, C. sake, Saccharomyces bailii, S. bisporus, S. cerevisiae, S. rouxii, S. bayanus, Brettanomyces intermedius,
Schizosaccharomyces pombe, Torulopsis holmii, Hanseniaspora guilliermondii, Schwanniomyces occidentalis, Dekkera bruxellensis, D. naardenensis Torulaspora delbrueckii, and Zygosaccharomyces microellipsoides [7]. Major yeast species found in citrus juices are Candida parapsilosis, C. stellata, Saccharomyces cerevisiae, Torulaspora delbrueckii, and Zygosaccharomyces rouxii [26]. Some of these species are sensitive to thermal pasteurization treatment applied to fruit juices [6].

3.1. Yeasts Resistant to Preservatives. Resistance to preservatives is a great threat to the stability of fruit juices [27]. Examples of yeasts resistant to preservatives include Zygosaccharomyces bailli, Candida krusei, Saccharomyces bisporus, Schizosaccharomyces pombe, and Pichia membranifaciens [27, 28]. Resistance to preservatives has been attributed to the ability of cells to tolerate chronic intracellular $\mathrm{pH}$ drops by phosphofructokinase enzyme [6]. P. membranifaciens is resistant to heat, moderate amount of salt, $\mathrm{SO}_{2}$, sorbic, benzoic and acetic acid; hence, it is considered as target microorganism for optimization of thermal pasteurization [7].

\section{Moulds}

Moulds are aerobic which grow at low $\mathrm{pH}$ and high sugar concentration. In response to thermal treatment, moulds are divided into two categories: heat labile and heat resistant [29, 30]. Former kinds produce mycelial mats in juice and adhere to the package interior, carton seams and produce musty and stale off-flavours. Juice cloud loss occurs through the activity of pectinesterases $[6,29]$. The dominant moulds recorded in fruit juices belong to Penicillium sp., Cladosporium sp., Aspergillus niger, A. fumigatus, Botrytis sp., and Aureobasidium pullulans [25]. Rhizopus and Mucor are also associated with spoilage of fresh fruits and vegetables [30]. Among these, some moulds produce mycotoxins which are of great threat to human health. Major mycotoxins associated with fruit juices are byssochlamic acid (Byssochlamys fulva, B. nivea), patulin (B. fulva, B. nivea, and P. expansum), ochratoxin (Aspergillus carbonarius), and citrinin (Penicillium expansum, $P$. citrinum) $[29,31]$. Presence of patulin in fruit juices is indicator of poor quality of fruits used in processing of juices [32].

4.1. Heat Resistant Moulds. The moulds, which able to survive at $85^{\circ} \mathrm{C}$ for 4.5 minutes, low oxygen tension, low $\mathrm{pH}$ (3.04.5 ) and produce pectinolytic enzymes, have an influence on juice stability [24]. Some notable species are Byssochlamys fulva, B. nivea, Neosartorya fischeri, and Talaromyces [6, 24, 33]. These moulds survive commercial heat pasteurization treatment, usually applied to fruits and fruit products because of the presence of heat resistant ascospores [6, 25, 34]. Heat resistance also depends upon the fruit product. As the concentration of sugar increases, heat resistance in microorganisms also increases [6, 24, 33].

The presence of heat resistant fungi such as Paecilomyces variotii, Aspergillus tamari, A. flavus, and A. ochraceus has been reported in sixty packaged Nigerian fruit juices 
TABLE 1: Thermal tolerance level of heat resistant moulds.

\begin{tabular}{lll}
\hline Heat resistant moulds & Thermal tolerance level & References \\
\hline Talaromyces flavus & $100^{\circ} \mathrm{C}$ for 5 to 12 minutes in many fruit syrups \\
Byssochlamys fulva & $86^{\circ}$ to $88^{\circ} \mathrm{C}$ for 30 minutes & {$[24]$} \\
Paecilomyces variotii, Fusarium sp. & $95^{\circ} \mathrm{C}$ for $10-20$ seconds & {$[90]$} \\
\hline
\end{tabular}

consisting of mango, pineapple, orange, and tomato [35]. Chlamydospores, sclerotia, and aleurospores are the resistant structures/spores produced by these moulds $[34,36]$.

A pasteurization temperature for fruit and fruit products often tested is $90^{\circ} \mathrm{C}$ for 3 minutes. This treatment may not be adequate to inactivate ascospores of Byssochlamys fulva, Neosartorya fischeri, and Talaromyces species [24]. Salomão et al. [34] reported that the thermal tolerance level of the ascospores of heat resistant moulds varies from strain to strain and with the composition of the heating medium as explained in Table 1.

The sources of contamination of these ascospores of heat resistant fungi found in fruit juices are soil, especially in case of grapes, passion fruits, pineapples, mangoes, strawberries, and other berries [6]. Other sources of contamination are processing facilities, air, utensils, fields, and orchards [24].

\section{Bacteria}

Bacteria are present in low numbers on fresh fruits and vegetables due to low $\mathrm{pH}$. Acid tolerant bacteria such as heterofermentative lactic acid bacteria, acetic acid bacteria, Erwinia sp., Enterobacter sp., Clostridium, Alicyclobacillus acidoterrestris, Propionibacterium cyclohexanicum, Pseudomonas sp., and Bacillus sp. have been reported as deteriorative in fruit juices $[7,19]$ which are discussed here.

5.1. Lactic Acid Bacteria (LAB). Lactic acid bacteria are gram positive, rod shaped, and catalase negative. Heterofermentative lactic acid bacteria were reported as the most important group of spoilage microorganisms in fruit juices [25]. Lactobacillus and Leuconostoc are the two taxa frequently isolated from fruits and spoiled fruit juices [6]. They produce lactic acids in fruit juices along with lesser amount of acetic and gluconic acids, ethanol and $\mathrm{CO}_{2}$, but some species of lactic acid bacteria such as L. mesenteroides ssp. cremoris, Leuconostoc paramesenteroides, and Leuconostoc dextranicum are more prominent as they produce diacetyl and acetoin as metabolites in spoiled fruit juices, contributing to buttery or butter milk off flavor to citrus juices $[6,13,25]$.

5.2. Acetic Acid Bacteria. Acetic acid bacteria belong to three taxa, namely, Acetobacter, Gluconobacter, and Gluconacetobacter. These are gram negative or gram variable, aerobic, ellipsoidal to rod shaped cells that can occur in chains, single or in pairs and are among the main spoilage bacteria because they have the ability to grow at relatively low $\mathrm{pH}$ and low nutrient levels. Production of sour and vinegar like flavours in fruit juices is due to the formation of acetic acid by these bacteria $[6,25,37]$.

5.3. Alicyclobacilli. In recent years, Alicyclobacillus a thermoacidophilic, endospore producing bacterium has emerged as major concern to the beverage industry worldwide as many high concentrated fruit products which are valuable semiprepared food components to the bakery, dairy, canning, baby foods, and distilling and beverage industries have been found to be contaminated with these spoilage microbes [13]. The thermoacidophilic nature and presence of highly resistant endospores is responsible for their survival during the production of concentrated fruit products. Soil is considered to be the main source of contamination of fresh fruits during harvesting. Some alicyclobacilli are soil borne microbes [38-42]. This bacterium was first classified as Bacillus acidocaldarius followed by $B$. acidoterrestris and now assigned to new genus Alicyclobacillus $[6,10,12,13,33,43,44]$.

Of the over 20 species of Alicyclobacillus isolated from different environments. Some of them are Alicyclobacillus acidocaldarius, A. hesperidium, A. acidophilus, A. cyclohaptanicus, $A$. fastidious, and $A$. pomorum have been implicated in spoilage incidents in high acid fruit and vegetable products [45]. Alicyclobacillus acidoterrestris has emerged as new spoilage bacterium for commercialized fruit juices that can survive pasteurization at $95^{\circ} \mathrm{C}$ for 2 minutes and can spoil heat treated fruit juices by the formation of taint chemicals (guaiacol and halophenolic) [13, 46].

Pathogenicity of Alicyclobacillus acidoterrestris and $A$. caldarious strains have extensively been studied [38]. Alicyclobacillus contains $\omega$-alicyclic fatty acids ( $\omega$-cyclohexane and $\omega$-cycloheptane fatty acids) in their cell membrane that are responsible for heat resistance of Alicyclobacillus by forming a protective coating with strong hydrophobic bonds. These hydrophobic bonds stabilize reduced membrane permeability in extreme and high temperature environments $[43,44]$. Another factor contributing to the heat stability of Alicyclobacillus is its endospores along with presence of heat stable proteins and mineralization by divalent cations especially calcium-dipicolinate complex $[44,47,48]$.

Contamination of Alicyclobacillus in fruit juices results from sources like soil, water, and processing facilities [44]. Spoilage of fruit juices by Alicyclobacillus is difficult to detect because it does not produce any visible changes such as gas during growth and incipient swelling of containers does not occur so that spoilage in retail products cannot be noticed $[33,49]$. It produces a smoky, medicinal, and antiseptic off-odour associated with guaiacol. Other compounds such as 2,6-dibromophenol and 2,6-dichlorophenol have also been found $[46,50,51]$. Endospores of Alicyclobacillus have 
TABLE 2: Human pathogens isolated from street sold unpasteurized fruit juices.

\begin{tabular}{lll}
\hline Place & Fruit juice & Pathogens \\
\hline $\begin{array}{l}\text { Vishakhapatnam (India) } \\
\text { Mumbai (India) }\end{array}$ & $\begin{array}{l}\text { Orange, pomegranate, mango, pine apple, } \\
\text { and grape }\end{array}$ & Faecal coliforms and faecal streptococci \\
\hline $\begin{array}{l}\text { Jimma town (South west } \\
\text { Ethiopia) }\end{array}$ & Avocado, papaya, and pine apple & $\begin{array}{l}\text { Vibrio cholerae, Escherichia coli, and } \\
\text { Staphylococcus aureus }\end{array}$ \\
\hline Nagpur (India) & Pine apple, sweet lime, and carrot juice & Klebsiella, Enterobacter, and Serratia \\
\hline Amravati (India) & $\begin{array}{l}\text { Apple, orange, pineapple, pomegranate, } \\
\text { sweet lemon, and mix fruit }\end{array}$ & $\begin{array}{l}\text { Salmonella, Coliforms, S. aureus, } \\
\text { Pseudomonas, and Proteus }\end{array}$ \\
\hline
\end{tabular}

$\mathrm{D}$ values in the range of $16-23$ minutes at $90^{\circ} \mathrm{C}$, greater than the pasteurization treatments applied in fruit juice processing [12]. Hence, Silva and Gibbs [33] suggested that Alicyclobacillus is to be designated as the target microbe in the design of pasteurization processes for acidic foods and beverages.

\subsubsection{Propionibacterium cyclohexanicum. Propionibacterium} cyclohexanicum, a gram positive, acid tolerant, heat resistant, nonmotile pleomorphic rod shaped bacterium first isolated from spoiled orange juice in 1993 [52]. It possesses $\omega$ cyclohexyl undecanoic acid in cell membrane as Alicyclobacillus genus but lacks the production of endospores [11]. Walker and Phillips [10] reported that Propionibacterium cyclohexanicum survives at $95^{\circ} \mathrm{C}$ for 10 minutes in orange juice and hence would survive treatments commonly used in pasteurization process used in fruit juice industry.

5.3.2. Streptomyces. Streptomyces is a gram positive, filamentous rod shaped soil bacterium, possesses spores in chains. Streptomyces griseus is frequently found in spoiled apple juice. This bacterium enters into fruit juices through poorly washed fruits that are contaminated with soil [53]. It produces earthy like off-flavour in juices attributable to the presence of compounds like geosmin, 2-methyl isoborneol, and 2isobutyl-3-methoxy pyrazine [8].

5.3.3. Bacillus. Bacillus coagulans, B. marcesens, and B. polymyxa are gram positive, rod shaped, and endospore producers often spoil various fruit juices [54]. Bacillus coagulans spoils canned tomato juice and vegetable products. It causes flat sour spoilage in juice $[6,13,33,55]$.

5.3.4. Clostridium. Two species of Clostridium mainly $C$. pasteurianum and C. butyricum, gram positive, anaerobic endospore forming bacterium, have been isolated at low $\mathrm{pH}$ of fruit juices [54].

\section{Pathogenic Microorganisms}

Fruit surfaces can be contaminated with feces and feces present on fruit surfaces can contaminate the washing water and permit the internalization of food borne pathogens which help in their survival under the acidic conditions of fruit juices $[8,56]$. Some strains of Escherichia coli, Shigella, and Salmonella may survive for several days and even weeks in acidic environment by regulating their internal $\mathrm{pH}$ that maintained at neutral $\mathrm{pH}$ by combination of passive and active mechanisms [9].

Shigella flexneri and S. sonnei survive in apple juice ( $\mathrm{pH}$ 3.3) and tomato juice $(\mathrm{pH} 4.0)$ at $7^{\circ} \mathrm{C}$ for at least 14 days [57]. Sospedra et al. [14] reported the presence of Salmonella sp. and Staphylococcus aureus in orange juice extracted by squeezing machine used in restaurants. Several studies carried out by researchers on pathogenic microorganisms associated with street vended unpasteurized fruit juices [5862] as summarized in Table 2.

Because of the presence of pathogens in fruit juices, the food borne outbreaks associated with consumption of fruit juices have been increased $[9,14,19,63,64]$. Fruit juice borne outbreaks of last two decades from 1991-2010 are summarized in Table 3. Several outbreaks associated with consumption of fruit juices have been reported maximum in year 1999 (5) $[59,65-67]$ and 1996 (4) [68-70]. E. coli O157:H7 is associated with large number of outbreaks attributable to consumption of unpasteurized apple juice. Salmonella is main causal organism for outbreaks related to unpasteurized orange juice. Clostridium botulinum is reported from homemade as well as pasteurized carrot juice. Vibrio cholorae has been reported for outbreak in India by the consumption of unpasteurized sugarcane juice (Table 3). In year 1999, 423 people in the USA and Canada and 405 people in Australia were affected by consuming unpasteurized orange juice [59].

\section{Isolation of Spoilage Microorganisms from Fruit Juices}

Microbiological examination of fruit juices is done by serial dilution pour plate methods [71]. For total aciduric microbial populations, orange serum agar $(\mathrm{pH}-5.5$, Orange Serum $200 \mathrm{~mL} / \mathrm{L}$; Yeast Extract-3 g/L; Enzymatic Digest of Casein-10 g/L; Dextrose-4 g/L; Potassium Phosphate$2.5 \mathrm{~g} / \mathrm{L}$; Agar $-17 \mathrm{~g} / \mathrm{L}$ ) is used. Potato dextrose agar (PDA) ( $\mathrm{pH}-3.5$, potato $-200 \mathrm{~g} / \mathrm{L}$; dextrose $-20 \mathrm{~g} / \mathrm{L}$, agar-15 g/L), PDA with antibiotics ( $\mathrm{pH}-5.6)$, malt extract agar (MEA) ( $\mathrm{pH}-5.5$; Malt extract-30 g/L; Mycological peptone-5 g/L; Agar $15 \mathrm{~g} / \mathrm{L})$ supplemented with chloramphenicol $(100 \mathrm{mg} / \mathrm{L}$, added before autoclaving) are used for enumeration of yeasts 
TABLE 3: Fruit juice borne outbreaks caused by pathogenic bacteria from 1991 to 2010.

\begin{tabular}{|c|c|c|c|c|c|c|}
\hline Type of fruit juices & Pathogens & Year & Country & Venue & $\begin{array}{c}\text { Number of cases } \\
\text { (deaths) }\end{array}$ & Reference \\
\hline Unpasteurized apple juice & Escherichia coli $\mathrm{O} 157: \mathrm{H} 7$ & 1991 & USA & Small cider mill & $23(0)$ & [91] \\
\hline Unpasteurized orange juice & Enterotoxigenic E. coli & 1992 & India & $\begin{array}{l}\text { Roadside } \\
\text { vendor }\end{array}$ & $6(0)$ & {$[92]$} \\
\hline Unpasteurized apple juice & Cryptosporidium & 1993 & USA & School & $213(0)$ & {$[93]$} \\
\hline Carrot homemade juice & Clostridium botulinum & 1993 & USA & Home & $1(0)$ & {$[94]$} \\
\hline Unpasteurized orange juice & $\begin{array}{l}\text { Salmonella gaminara, } S . \\
\text { hartford, and S. rubislaw }\end{array}$ & 1995 & USA & Retail & $63(0)$ & [95-97] \\
\hline Unpasteurized orange juice & Shigella flexneri & 1995 & South Africa & Restaurant & $14(0)$ & [98] \\
\hline Unpasteurized apple juice & C. parvum & 1996 & USA & Small cider mill & $31(0)$ & {$[68]$} \\
\hline Unpasteurized apple juice & E. coli $\mathrm{O} 157: \mathrm{H} 7$ & 1996 & USA & Small cider mill & $14(0)$ & {$[68]$} \\
\hline Unpasteurized apple juice & E. coli $\mathrm{O} 157: \mathrm{H} 7$ & 1996 & USA & Small cider mill & $6(0)$ & {$[70]$} \\
\hline Unpasteurized apple juice & E. coli $\mathrm{O} 157: \mathrm{H7}$ & 1996 & Canada, USA & Retail & $70(1)$ & {$[69,99]$} \\
\hline Unpasteurized apple juice & E. coli $\mathrm{O} 157: \mathrm{H7}$ & 1998 & Canada & Farm/home & $14(0)$ & {$[100]$} \\
\hline Unpasteurized apple juice & E. coli $\mathrm{O} 157: \mathrm{H7}$ & 1999 & USA & Not reported & $25(0)$ & {$[67]$} \\
\hline Unpasteurized orange juice & S. muenchen & 1999 & Canada, USA & Restaurant & $423(1)$ & [65] \\
\hline Unpasteurized orange juice & S. anatum & 1999 & USA & Roadside stand & $6(0)$ & {$[66]$} \\
\hline Unpasteurized orange juice & S. typhimurium & 1999 & Australia & Retail & $405(0)$ & {$[59]$} \\
\hline Unpasteurized sugar cane juice & Vibrio cholerae & 1999 & India & Not reported & - & {$[59]$} \\
\hline Unpasteurized orange juice & S. enteritidis & 2000 & USA & $\begin{array}{l}\text { Retail and food } \\
\text { service }\end{array}$ & $88(0)$ & {$[101]$} \\
\hline Unpasteurized apple juice & C. parvum & 2003 & USA & Farm/retail & $144(0)$ & {$[102]$} \\
\hline Unpasteurized apple juice & E. coli O111 and C. parvum & 2004 & USA & Farm/home & $212(0)$ & {$[102]$} \\
\hline Unpasteurized orange juice & $\begin{array}{l}\text { S. typhimurium and } S \text {. } \\
\text { saintpaul }\end{array}$ & 2005 & USA & $\begin{array}{l}\text { Retail and food } \\
\text { service }\end{array}$ & $152(0)$ & {$[103]$} \\
\hline Unpasteurized sugar cane juice & Trypanosoma cruzi & 2005 & Brazil & Roadside kiosk & $25(3)$ & {$[104]$} \\
\hline Pasteurized carrot juice & C. botulinum & 2006 & USA & Retail & $4(0)$ & {$[105]$} \\
\hline Unpasteurized apple juice & E. coli $\mathrm{O} 157: \mathrm{H7}$ & 2007 & USA & Not reported & $9(0)$ & {$[67]$} \\
\hline Unpasteurized apple juice & E. coli $\mathrm{O} 157: \mathrm{H7}$ & 2008 & USA & Retail & 7 & {$[67]$} \\
\hline Unpasteurized orange juice & S. panama & 2008 & Netherlands & Not reported & $33(0)$ & {$[7]$} \\
\hline Unpasteurized apple juice & E. coli $\mathrm{O} 157: \mathrm{H} 7$ & 2010 & USA & Fair & $7(0)$ & [106] \\
\hline
\end{tabular}

and moulds at incubation temperature of $25^{\circ} \mathrm{C}$ for 3 and 7 days for yeasts and moulds, respectively [25].

Isolation of yeasts resistant to preservatives from fruit juices is done by plating on MEA with $0.5 \%$ acetic acid and tryptone glucose yeast extract agar (TGY) ( $\mathrm{pH}-7.0$, Casein enzymatic hydrolysate $-5 \mathrm{~g} / \mathrm{L}$; Yeast extract $-3 \mathrm{~g} / \mathrm{L}$; Glucose-1 g/L; Agar-15 g/L) with $0.5 \%$ acetic acid at 25$30^{\circ} \mathrm{C}$ for $3-5$ days. For the isolation of heat resistant fungi, fruit sample must be treated in water bath at $75^{\circ} \mathrm{C}$ to $80^{\circ} \mathrm{C}$ for 1.5 hour and isolated by using PDA, OSA, and MEA media [25].

PDA at $\mathrm{pH} 3.7$ and OSA at $\mathrm{pH} 5.5$ at an incubation temperature of $50^{\circ} \mathrm{C}$ for 3 days are the best isolation media for the detection and isolation of Alicyclobacillus sp. from fruit juices and concentrates [46]. Further identification of moulds and yeasts is done by using methods and media described in Samson et al. [72] and identification of bacterial isolates is done by using methods described in Bergey's Manual of
Systematic Bacteriology [73] as well as by using advanced DNA-sequencing techniques.

\section{Prevention of Spoilage and Pathogenic Microorganisms in Fruit Juices}

There are various techniques to prevent pathogenic as well as nonpathogenic microflora such as chilling, freezing, water activity, modified atmosphere packaging, pasteurization, nonthermal physical techniques, and by addition of natural antimicrobials [19]. The most common method to inactivate microorganisms and enzymes for increasing the shelf life of fruit juices is by thermal processing; however, loss of original taste and flavor compounds occur in fruit juices. These negative effects have motivated a great interest in the development of new technology that offer advantages of using low processing temperatures, low energy consumption, and 
TABLE 4: Effect of high hydrostatic pressure on microorganisms in fruit juices.

\begin{tabular}{|c|c|c|c|c|}
\hline Fruit juice(s) & Target microorganisms & Treatment parameters & Log reduction & References \\
\hline Orange juice & $\begin{array}{l}\text { Escherichia coli } \\
\text { O157:H7 }\end{array}$ & $550 \mathrm{MPa}, 30^{\circ} \mathrm{C}, 5 \mathrm{~min}$ & 6 & {$[107]$} \\
\hline Apple juice & E. coli 29055 & $400 \mathrm{MPa}, 25^{\circ} \mathrm{C}$ & $>5$ & {$[108]$} \\
\hline $\begin{array}{l}\text { Apricot, sour cherry, and } \\
\text { apple juices }\end{array}$ & $\begin{array}{l}\text { Staphylococcus aureus } \\
\text { E. coli O157:H7, } \\
\text { Salmonella enteritidis }\end{array}$ & $\begin{array}{c}350 \mathrm{MPa}, 30^{\circ} \mathrm{C}, 5 \\
\text { minutes }\end{array}$ & $>5$ & [109] \\
\hline Apple juice & $\begin{array}{l}\text { E. coli, Listeria innocua, and } \\
\text { Salmonella }\end{array}$ & $545 \mathrm{MPa}, 1 \mathrm{~min}$ & 5 & {$[110]$} \\
\hline Orange juice & E. coli, L. innocua & $241 \mathrm{MPa}, 3 \mathrm{~min}$ & 5 & {$[111]$} \\
\hline
\end{tabular}

high retention of nutritional and sensory properties of the food and improving its microbiological quality [17].

\section{Thermal Pasteurization}

FDA has recommended $5 \log _{10}$ reduction of infection pathogens in a fruit juice which can be achieved by pasteurization at $90-95^{\circ} \mathrm{C}$ for $4-10$ seconds $[4,6]$. This pasteurization temperature is effective against E. coli and Salmonella [50] but is not effective against ascospores of heat resistant fungi $[34,74]$ and heat resistant bacteria $[13,44,49,50]$. In addition, the thermal pasteurization damages nutritional and physiochemical properties of fruit juices [4].

Nonthermal preservative methods are receiving good attention because of their potential for quality and safety improvement of food [15]. Some of the nonthermal processes used in food industries are high intensity pulsed electric field (HIPEF), high hydrostatic pressure (HHP), high pressure homogenization (HPH), ultraviolet (UV), ultrasound, and irradiation. These novel nonthermal technologies have the ability to inactivate microorganisms at ambient or near ambient temperatures, thus avoiding the deleterious effect of heat has on flavor, colour, and nutrient value of foods mean effect of thermal treatment on fruit juices [84]. Apart from these methods, sodium benzoate and potassium sorbate are two of the most commonly used chemical preservatives to increase the shelf life of fruit juices. But consumer demand for safe, natural, and environmental friendly food preservatives has been increasing. Natural antimicrobials such as bacteriocins, lactoperoxidase, herbs, leaves, oils, and spices have shown potential for use in some food products [18]. Some of the common nonthermal methods used in fruit juice industry are described below.

\section{High Hydrostatic Pressure (HHP)}

High hydrostatic pressure is commercially used worldwide for a variety of foods such as cooked meat, shellfish, fruit, and vegetable juices, sauces, and dips [75]. In this process, fruit juices are subjected to $400 \mathrm{MPa}$ pressure for a few minutes at $20^{\circ} \mathrm{C}$ or below which is sufficient to reduce the numbers of spoilage microorganisms such as yeasts, moulds, and lactic acid bacteria $[75,76]$. The HHP treatment has a lethal effect on microorganisms by affecting their cell membrane along with inactivation of some key enzymes which are involved in DNA replication and transcription processes [15, 75]. Bacterial spores are resistant to HHP treatment and they can survive up to pressure of $1000 \mathrm{MPa}$ [76]. This process has great potential to reduce the microbial load of fruit juices and increase the shelf life of fruit juices (Table 4).

\section{High Pressure Homogenization (HPH)}

It involves the pumping of liquid through homogenizing valve at high pressure over $100 \mathrm{MPa}$. It produces high turbulence and shear along with compression, acceleration, and pressure drop result in the breakdown of particles and dispersion throughout the product. After homogenization, the particles of uniform size in the range from $0.2 \mu \mathrm{m}$ to $2 \mu \mathrm{m}$ are obtained [16]. In the past, $\mathrm{HPH}$ was purposed as a suitable method for the stabilization of dairy products but in last decades it has been suggested for its use for prolongation of the shelf life of fruit juices [22]. HPH inactivates microorganisms by damaging their structural integrity coupled with sudden rise in temperature produced in this process [75]. Table 5 summarizes the effect of $\mathrm{HPH}$ on the reduction of microbial load of fruit juices.

\section{Pulsed Electric Field (PEF)}

PEF involves the application of short duration and high intensity electric field pulses. The fluid foods are placed between two electrodes in batch and continuous flow treatment [17]. This process inactivates microorganisms and enzymes with only small increase in temperature [77], affects the cell membrane of microorganisms by electroporation which leads to leakage of cytoplasmic content from cells $[78,79]$. The work carried out on the inactivation of microorganisms in fruit juices by PEF treatment is summarized in Table 6 .

\section{Ultraviolet Technology (UV)}

Ultraviolet technology has been utilized in the food industry to disinfect water and effectively destroy microorganisms on surfaces and packaging [80]. Ultraviolet radiation involves the use of radiation from electromagnetic spectrum from 100 to $400 \mathrm{~nm}$. It is classified as UV-A (320-400 nm), UV-B 
TABLE 5: Effect of high pressure homogenization on microorganisms in fruit juices.

\begin{tabular}{|c|c|c|c|c|}
\hline Fruit juice(s) & Target microorganisms & Treatment parameters & Log reduction & References \\
\hline Orange juice & $\begin{array}{l}\text { Escherichia coli } \mathrm{O} 58: \mathrm{H} 21 \\
\text { ATCC } 10536 \\
\text { E. coli O157:H7 CCUG } 44857\end{array}$ & $300 \mathrm{MPa}$ & 4 & {$[112]$} \\
\hline Orange juice & $\begin{array}{l}\text { Saccharomyces cerevisiae, Lactobacillus } \\
\text { plantarum }\end{array}$ & $>250 \mathrm{MPa}$ & $>5$ & {$[113]$} \\
\hline Apple juice & $\begin{array}{l}\text { Saccharomyces, Penicillium, } \\
\text { Aureobasidium, and Aspergillus }\end{array}$ & $300 \mathrm{MPa}$ & $>5$ & {$[114]$} \\
\hline Apricot juice & S. cerevisiae & $100 \mathrm{MPa}$ (4 times) & 2.2 & {$[115]$} \\
\hline Carrot juice & S. cerevisiae & $100 \mathrm{MPa}$ (3 times) & 3 & {$[115]$} \\
\hline Apricot juice & Zygosaccharomyces bailli & $100 \mathrm{MPa}$ (8 times) & 2.5 & {$[116]$} \\
\hline Carrot juice & Z. bailli & $100 \mathrm{MPa}$ (8 times) & 2.5 & {$[116]$} \\
\hline
\end{tabular}

TABLE 6: Effect of pulsed electric field on microorganisms in fruit juices.

\begin{tabular}{|c|c|c|c|c|}
\hline Fruit juice(s) & Target microorganisms & Treatment parameters & Log reduction & Reference \\
\hline Apple juice & Escherichia coli 8739, E. coli O157:H7 & $30 \mathrm{kV} / \mathrm{cm}, 172 \mu \mathrm{s},<35^{\circ} \mathrm{C}$ & 5 & {$[117]$} \\
\hline Cranberry juice & Total aerobic count, moulds, and yeasts & $40 \mathrm{kV} / \mathrm{cm}, 150 \mu \mathrm{s},<25^{\circ} \mathrm{C}$ & 4 & {$[118]$} \\
\hline Apple juice & E. coli $\mathrm{O} 157: \mathrm{H7}$ & $34 \mathrm{kV} / \mathrm{cm}, 166 \mu \mathrm{s}$ & 4.5 & {$[119]$} \\
\hline Orange juice & Listeria innocua & $30 \mathrm{kV} / \mathrm{cm}, 12 \mu \mathrm{s}, 54^{\circ} \mathrm{C}$ & 6.0 & {$[120]$} \\
\hline Apple cider & E. coli $\mathrm{O} 157: \mathrm{H7}$ & $90 \mathrm{kV} / \mathrm{cm}, 20 \mu \mathrm{s}, 42^{\circ} \mathrm{C}$ & 5.9 & {$[121]$} \\
\hline Orange juice & Salmonella typhimurium & $90 \mathrm{kV} / \mathrm{cm}, 100 \mu \mathrm{s}, 55^{\circ} \mathrm{C}$ & 5.9 & {$[122]$} \\
\hline Apple juice & E. coli & $34 \mathrm{kV} / \mathrm{cm}, 7.68 \mu \mathrm{s}, 55^{\circ} \mathrm{C}$ & 6.2 & {$[123]$} \\
\hline Grape juice & E. coli & $34 \mathrm{kV} / \mathrm{cm}, 7.68 \mu \mathrm{s}, 55^{\circ} \mathrm{C}$ & 6.4 & {$[123]$} \\
\hline Orange juice & Lactobacillus brevis & $35 \mathrm{kV} / \mathrm{cm}, 2.5-5.0 \mu \mathrm{s}$ & 5.8 & {$[124]$} \\
\hline $\begin{array}{l}\text { Orange juice-milk } \\
\text { mixture }\end{array}$ & L. plantarum & $35 \mathrm{kV} / \mathrm{cm}, 2.5-5.0 \mu \mathrm{s}$ & 2.5 & {$[125]$} \\
\hline Apple juice & E. coli & $\begin{array}{l}36 \mathrm{kV} / \mathrm{cm}, 800 \text { pulse s per } \\
\text { second }\end{array}$ & 6 & {$[77]$} \\
\hline Cherry juice & Penicillium expansum & $34 \mathrm{kV} / \mathrm{cm}, 163 \mu \mathrm{s}, 21^{\circ} \mathrm{C}$ & $100 \%$ inactivation of spore germination & {$[126]$} \\
\hline Orange juice & Salmonella enteritidis, E. coli & $35 \mathrm{kV} / \mathrm{cm}, 4 \mu \mathrm{s}, 40^{\circ} \mathrm{C}$ & 5 & [17] \\
\hline \multirow{3}{*}{ Strawberry juice } & \multirow{3}{*}{ E. coli $\mathrm{O} 157: \mathrm{H7}$} & $18.6 \mathrm{kV} / \mathrm{cm}, 150 \mu \mathrm{s}, 45^{\circ} \mathrm{C}$ & 3.09 & \multirow{3}{*}[79]{} \\
\hline & & $18.6 \mathrm{kV} / \mathrm{cm}, 150 \mu \mathrm{s}, 50^{\circ} \mathrm{C}$ & 4.08 & \\
\hline & & $18.6 \mathrm{kV} / \mathrm{cm}, 150 \mu \mathrm{s}, 55^{\circ} \mathrm{C}$ & 4.71 & \\
\hline
\end{tabular}

$(280-320 \mathrm{~nm})$, and UV-C $(200-280 \mathrm{~nm})$ [81]. UV-C is effective against bacteria and viruses [81]. UV treatment is performed at low temperature. $254 \mathrm{~nm}$ wavelength of UV light is widely used in juice and beverage industry [18]. UV-C light inactivates microorganisms by damaging their DNA that absorbs UV light from 200 to $310 \mathrm{~nm}$. UV creates the pyrimidine dimers which prevent microorganisms from replicating and thus rendering them inactive [81]. Novel works carried out on the effect of UV-C on the microbial load in different fruit juices have been given in Table 7 .

\section{Ultrasound}

Power ultrasound has been identified as potential technology to meet US Food and Drug Administration (USFDA) requirement of $5 \mathrm{log}$ reduction of Escherichia coli in fruit juices. High power ultrasound causes bubble cavitation in a liquid due to pressure changes. These resultant microbubbles collapse violently in the succeeding compression cycles of propagated ultrasonic waves resulting in localized high temperature up to $5000 \mathrm{~K}$, pressures up to $50,000 \mathrm{kPa}$, and high shearing effects causing breakdown of cell walls, disruption of cell membranes, and damage of DNA of microorganisms $[18,82,83]$. Destruction of microorganisms in fruit juices by ultrasound which has been studied by various researchers is summarized in Table 8 .

Nonthermal processes are to be used with caution in juices because they are not without harmful effects such as high hydrostatic pressure method which can alter the structure of protein and polysaccharide causing changes in the texture, physical appearance, and functionality of foods. High intensity ultrasound can denature proteins and produce free radicals that can adversely have an effect on the flavor of 
TABLE 7: Effect of ultraviolet on microorganisms in fruit juices.

\begin{tabular}{|c|c|c|c|c|}
\hline Fruit juice & Target microorganisms & Treatment parameters $\mathrm{mJ} / \mathrm{cm}^{2}$ & $\begin{array}{c}\log \\
\text { reduction }\end{array}$ & References \\
\hline Apple juice & Escherichia coli $\mathrm{K} 12$ & 14.5 & $3-4$ & [127] \\
\hline Orange juice & Yeasts, moulds & $12.3-120$ & 3 & [128] \\
\hline Apple juice & Saccharomyces cerevisiae, Listeria innocua, and E. coli & 5135 & $\begin{array}{l}1.34 \\
4.29 \\
5.10\end{array}$ & [129] \\
\hline Apple juice & ${ }^{*} \mathrm{APC}$ & $229.5 \mathrm{~J} / \mathrm{L}$ & 3.5 & \\
\hline \multirow{2}{*}{ Guava pineapple } & Yeasts & $1377 \mathrm{~J} / \mathrm{L}$ & 3.0 & \\
\hline & Moulds & & 4.48 & \\
\hline \multirow{3}{*}{ Orange juice 1} & APC & & & {$[81]$} \\
\hline & Yeasts & $167 \mathrm{~J} / \mathrm{L}$ & 1.32 & \\
\hline & Moulds & & & \\
\hline \multirow{3}{*}{ Orange juice 2} & APC & & & \\
\hline & Yeasts & $167 \mathrm{~J} / \mathrm{L}$ & $<1$ & \\
\hline & Moulds & & & \\
\hline
\end{tabular}

APC: aerobic plate count.

TABLE 8: Effect of ultrasound on microorganisms in fruit juices.

\begin{tabular}{|c|c|c|c|c|}
\hline Fruit juice(s) & Target microorganisms & Treatment parameters & Log reduction & References \\
\hline Carrot juice & Escherichia coli $\mathrm{K} 12$ & $\begin{array}{l}19.3 \mathrm{kHz}, 700-800 \mathrm{~W}, 1 \mathrm{~min}, \\
60^{\circ} \mathrm{C}\end{array}$ & 2.5 & {$[130]$} \\
\hline Orange juice & $\begin{array}{l}\text { Total mesophilic } \\
\text { Aerobes }\end{array}$ & $\begin{array}{l}500 \mathrm{kHz}, 240 \mathrm{~W}, 15 \mathrm{~min}, \\
60^{\circ} \mathrm{C}\end{array}$ & 3.4 & {$[131]$} \\
\hline Apple juice & $\begin{array}{l}\text { Alicyclobacillus } \\
\text { acidoterrestris }\end{array}$ & $24 \mathrm{kHz}, 300 \mathrm{~W}, 60 \mathrm{~min}$ & $80 \%$ & {$[132]$} \\
\hline \multirow[t]{2}{*}{ Orange juice } & $\begin{array}{l}\text { Aerobic mesophilic } \\
\text { count (AMC) }\end{array}$ & $20 \mathrm{kHz}, 500 \mathrm{~W}, 8 \mathrm{~min}, 10^{\circ} \mathrm{C}$ & 1.38 & \multirow{2}{*}[133]{} \\
\hline & $\begin{array}{l}\text { Yeast and mold } \\
\text { counts (YMC) }\end{array}$ & & 0.56 & \\
\hline
\end{tabular}

fruit based or high fat foods. Ultraviolet treatment is difficult to apply on fruit juices because of low UV transmittance through the juice because of high suspended and soluble solids [81]. Emerging nonthermal technology also has been so energy expensive or costly to be practical for use in food processing [84].

\section{Preservatives}

Another method to prevent microbial contamination in juice is by use of preservatives. Some chemical preservatives such as sodium benzoate and potassium sorbate are often used to prevent microbial spoilage of fruit juices $[8,18]$. Consumers relate synthetic preservatives as artificial products resulting in rejection of this type of food processed [8] so demands for preservatives which have natural origin have increased drastically.

Most of these natural antimicrobials have been considered as generally recognized as safe (GRAS). Natural antimicrobials are obtained from three natural sources such as plant (herb, spices, essential oil, and vanillin), animal (lactoperoxidase, lysozyme, chitosan), and microbes (bacteriocins) [19]. The antimicrobial activity of these compounds has been studied in fruit juices by many researchers as detailed given in Table 9 and employ different mechanisms to inactivate microorganisms.

Lactoperoxidase system produces hypothiocyanite $\left(\mathrm{OSCN}^{-}\right)$and hypothiocyanous acid (HOSCN), that possess antimicrobial effect by the oxidation of thiol group $\left({ }^{-} \mathrm{SH}\right)$ of cytoplasmic enzymes, damage to outer membrane, transport systems, glycolytic enzymes, and nucleic acids [85]. But lysozyme attack the bacterial peptidoglycan cell wall and are more effective against gram positive than gram negative bacteria because former contain about $90 \%$ peptidoglycan and later contain 5\% to $10 \%$ [19].

Chitosan is effective against microorganisms due to its positive charge amino group at $\mathrm{C}-2$ which can create polycationic structure and interact with anionic components such as lipopolysaccharide and proteins of cell surface; this binding disrupts the integrity of the outer membrane resulting in leakage of intracellular components [18]. Many herbs and 
TABLE 9: Effect of natural antimicrobials on spoilage and pathogenic microorganisms.

\begin{tabular}{|c|c|c|c|c|}
\hline Natural antimicrobial & Fruit juice & Target microorganisms & Log reduction & References \\
\hline Lactoperoxidase & Apple and orange juice & Escherichia coli, Shigella sp. & $>5$ & {$[64]$} \\
\hline Lysozyme & Orange juice & Salmonella typhimurium & - & {$[122]$} \\
\hline \multirow{2}{*}{ Chitosan } & \multirow{2}{*}{ Apple juice } & Yeasts and moulds & 3 & {$[134]$} \\
\hline & & Yeasts & $3-5$ & [135] \\
\hline Cinnamon powder & Apple juice & Listeria monocytogenes Scott 45954 & $4-6$ & [136] \\
\hline \multicolumn{5}{|l|}{ Essential oil } \\
\hline \multirow{5}{*}{ Cinnamon oil } & Apple, pear, melon juices & L. innocua, S. enteritidis, E. coli & 5 & [137] \\
\hline & & S. enteritidis & $3.1-3.9$ & \\
\hline & Melon, watermelon & E. coli & $1.4-1.9$ & [17] \\
\hline & & L. monocytogenes & $3.4-4.4$ & \\
\hline & Apple juice & S. hadar, E. coli $\mathrm{O} 157: \mathrm{H} 7$ & $50 \%$ & {$[138]$} \\
\hline \multirow{2}{*}{ Clove oil } & Apple juice & S. hadar, E. coli $\mathrm{O} 157: \mathrm{H7}$ & $50 \%$ & [138] \\
\hline & Tomato juice & Native microbiota & 3.9 & [139] \\
\hline Lemon oil & Apple juice & S. hadar, E. coli $\mathrm{O} 157: \mathrm{H} 7$ & $50 \%$ & {$[138]$} \\
\hline \multirow{2}{*}{ Lemongrass oil } & Apple, pear, melon juices & L. innocua, S. enteritidis, E. coli & 5 & [137] \\
\hline & Apple juice & S. hadar, E. coli $\mathrm{O} 157: \mathrm{H7}$ & $50 \%$ & {$[138]$} \\
\hline Lime oil & Apple juice & S. hadar, E. coli $\mathrm{O} 157: \mathrm{H7}$ & $50 \%$ & [138] \\
\hline Oregano oil & Apple juice & S. hadar, E. coli $\mathrm{O} 157: \mathrm{H} 7$ & $50 \%$ & [138] \\
\hline Carvacrol & Apple juice & S. hadar, E. coli $\mathrm{O} 157: \mathrm{H} 7$ & $50 \%$ & \\
\hline Cinnamaldehyde & Apple juice & S. hadar, E. coli $\mathrm{O} 157: \mathrm{H} 7$ & $50 \%$ & [139] \\
\hline \multirow{2}{*}{ Citral } & Apple juice & S. hadar, E. coli $\mathrm{O} 157: \mathrm{H} 7$ & $50 \%$ & [138] \\
\hline & Orange juice & L. monocytogenes & $1.1-1.3$ & {$[140]$} \\
\hline Eugenol & Apple juice & S. hadar, and E. coli $\mathrm{O} 157: \mathrm{H} 7$ & $50 \%$ & [138] \\
\hline
\end{tabular}

TABLE 10: Preservation of fruit juices by combination of different preservation methods.

\begin{tabular}{|c|c|c|c|c|}
\hline Fruit juice & $\begin{array}{l}\text { Combination of preservation } \\
\text { methods }\end{array}$ & Target microorganisms & Log reduction & References \\
\hline Orange juice & PEF with nisin & Native microflora & 6 & {$[141]$} \\
\hline Orange juice & PEF with nisin or lysozyme & Escherichia coli $\mathrm{O} 157: \mathrm{H} 7$ & $>7$ & {$[122]$} \\
\hline Strawberry juice & $\begin{array}{l}\text { PEF with cinnamon bark oil or } \\
\text { citric acid }\end{array}$ & E. coli O157:H7, Salmonella enteritidis & $>5$ & {$[17]$} \\
\hline Apple juice & $\begin{array}{l}\text { PEF with cinnamon bark oil or } \\
\text { citric acid }\end{array}$ & E. coli $\mathrm{O} 157: \mathrm{H7}$, S. enteritidis & $>5$ & {$[17]$} \\
\hline Pear juice & $\begin{array}{l}\text { PEF with cinnamon bark oil or } \\
\text { citric acid }\end{array}$ & E. coli $\mathrm{O} 157: \mathrm{H7}$, S. enteritidis & $>5$ & {$[17]$} \\
\hline Carrot juice & HPH with nisin & L. innocua & $>5$ & {$[142]$} \\
\hline Strawberry juice & $\begin{array}{l}\text { PEF with sodium benzoate and } \\
\text { potassium sorbate }\end{array}$ & E. coli O157:H7, S. enteritidis & 5.11 & {$[79]$} \\
\hline
\end{tabular}

plant extracts have broad spectrum activity against microorganisms [4, 86]. Essential oils are a group of terpenoids, sesquiterpenes, and possibly diterpenes with different groups of aliphatic hydrocarbons, acids, aldehydes, acyclic esters, or lactones. The antimicrobial activity of essential oil is not attributed to one specific mechanism, but there are several targets in the cell [87-89]. Hydrophobicity of essential oil enables them to partition in the lipids of bacterial cell membrane and mitochondria, disturbing the structures and rendering them more permeable [89].

Nisin possess narrow antimicrobial spectrum inhibiting only gram positive bacteria. It forms pore in cytoplasmic membrane of bacteria resulting in depletion of proton motive force and loss of cellular ions, amino acids, and ATP [19].

\section{Synergistic Effect of Physical and Natural Antimicrobials}

Food antimicrobials are generally biostatic and are not biocidal. Hence their effects on foods are limited. On the other hand use of combinations of antimicrobials [19] and antimicrobial along with nonthermal methods is effective against pathogenic and spoilage microorganisms. This combination improves the lethal effects of nonthermal processing and reduces the severity of nonthermal methods. So the combinations of these techniques could provide synergistic effects on prolonging the shelf life of fruit juices mentioned in Table 10 and potentially as best option for traditional pasteurization methods $[8,18]$. 


\section{Conclusion}

The demand for fruit juices has been increasing due to their health benefits. Due to change in dietary, social habits and preservation methods have led to increase in disease outbreaks linked mainly to fresh fruit juices in recent years. Pasteurization of fruit juices is very effective against a pathogenic and several spoilage microorganisms, nonetheless, sensory and nutritional properties are affected. To meet the demands for nutritious and safe foods has resulted in increased interest in nonthermal preservation techniques. The nonthermal methods described in this review have the potential to meet $5 \log$ microbial reductions. However, only high pressure processing has been used on pilot scale. There is also need for other nonthermal methods tested on pilot scale so they become alternative of pasteurization of fruit juices.

Application of different natural antimicrobials of animal, plant, and microbial origins directly or indirectly added to fruit juices effectively reduce or inhibit pathogenic and spoilage microorganisms. Thus they also represent good alternative of thermal processing of fruit juices.

In future, the combination of nonthermal methods and natural antimicrobial compounds would be new trend of preservation of fruit juices that improve the microbiological quality while having the lowest impacts on the organoleptic properties.

\section{Conflict of Interests}

The authors declare that there is no conflict of interests regarding the publication of this paper.

\section{References}

[1] K. R. Matthews, "Microorganisms associated with fruits and vegetables," in Microbiology of Fresh Produce, K. R. Matthews, Ed., pp. 1-19, ASM Press, Washington, DC, USA, 2006.

[2] S. Kumar, H. Thippareddi, J. Subbiah, S. Zivanovic, P. M. Davidson, and F. Harte, "Inactivation of Escherichia coli K-12 in apple juice using combination of high-pressure homogenization and chitosan," Journal of Food Science, vol. 74, pp. M8-M14, 2009.

[3] F. Patrignani, L. Vannini, S. L. S. Kamdem, R. Lanciotti, and M. E. Guerzoni, "Potentialities of high pressure homogenization to inactivate Zygosaccharomyces bailli in fruit juices," Journal of Food Science, vol. 75, no. 2, pp. M116-M120, 2010.

[4] J. Mosqueda-Melgar, R. M. Raybaudi-Massilia, and O. MartínBelloso, "Microbiological shelf life and sensory evaluation of fruit juices treated by high intensity electric fields and antimicrobials," Food and Bioproducts Processing, vol. 90, no. 2, pp. 205214, 2012.

[5] R. P. Bates, J. R. Morris, and P. G. Crandall, Principals and Practices of Small and Medium Scale Fruit Juice Processing, FAO Agricultural Services Bulletin, Rome, Italy, 2001.

[6] ICMSF, "Soft drinks, fruit juices, concentrates and food preserves," in Microorganisms in Foods 6: Microbial Ecology of Food Commodity, Kluwer Academic Publisher, 2005.

[7] A. Bevilacqua, M. R. Corbo, D. Campaniello et al., "Shelf life prolongation of fruit juices through essential oils and homogenization: a review," in Science against Microbial Pathogens:
Communicating Current Research and Technological Advances, pp. 1156-1166, 2011.

[8] A. A. Lima Tribst, A. De Souza Sant'ana, and P. R. De Massaguer, "Review: microbiological quality and safety of fruit juicespast, present and future perspectives Microbiology of fruit juices Tribst et al," Critical Reviews in Microbiology, vol. 35, no. 4, pp. 310-339, 2009.

[9] A. Vantarakis, M. Affifi, P. Kokkinos, M. Tsibouxi, and M. Papapetropoulou, "Occurrence of microorganisms of public health and spoilage significance in fruit juices sold in retail markets in Greece," Anaerobe, vol. 17, no. 6, pp. 288-291, 2011.

[10] M. Walker and C. A. Phillips, "The growth of Propionibacterium cyclohexanicum in fruit juices and its survival following elevated temperature treatments," Food Microbiology, vol. 24, no. 4, pp. 313-318, 2007.

[11] M. Walker and C. A. Phillips, "The effect of preservatives on Alicyclobacillus acidoterrestris and Propionibacterium cyclohexanicum in fruit juice," Food Control, vol. 19, no. 10, pp. 974-981, 2008.

[12] M. Walker and C. A. Phillips, "Alicyclobacillus acidoterrestris: an increasing threat to the fruit juice industry?" International Journal of Food Science and Technology, vol. 43, no. 2, pp. 250260, 2008.

[13] C. E. Steyn, M. Cameron, and R. C. Witthuhn, "Occurrence of Alicyclobacillus in the fruit processing environment-a review," International Journal of Food Microbiology, vol. 147, no. 1, pp. 111, 2011.

[14] I. Sospedra, J. Rubert, J. M. Soriano, and J. Mañes, "Incidence of microorganisms from fresh orange juice processed by squeezing machines," Food Control, vol. 23, no. 1, pp. 282-285, 2012.

[15] J. Kuldiloke and M. N. Eshtiaghi, "Application of non thermal processing for preservation of orange juice," KMITL Science Technology Journal, vol. 8, pp. 64-74, 2008.

[16] M. R. Corbo, A. Bevilacqua, D. Campaniello, C. Ciccarone, and M. Sinigaglia, "Use of high pressure homogenization as a mean to control the growth of foodborne moulds in tomato juice," Food Control, vol. 21, no. 11, pp. 1507-1511, 2010.

[17] J. Mosqueda-Melgar, R. M. Raybaudi-Massilia, and O. MartínBelloso, "Non-thermal pasteurization of fruit juices by combining high-intensity pulsed electric fields with natural antimicrobials," Innovative Food Science and Emerging Technologies, vol. 9, no. 3, pp. 328-340, 2008.

[18] H. P. V. Rupasinghe and L. J. Yu, "Emerging preservation methods for fruit juices and beverages," in Food Additive, Y. ElSamragy, Ed., InTech, 2012, http://www.intechopen.com/books/ food-additive/emerging-preservation-methods-3-for-fruitjuices-and-beverages.

[19] R. M. Raybaudi-Massilia, J. Mosqueda-Melgar, R. SolivaFortuny, and O. Martín-Belloso, "Control of pathogenic and spoilage microorganisms in fresh-cut fruits and fruit juices by traditional and alternative natural antimicrobials," Comprehensive Reviews in Food Science and Food Safety, vol. 8, no. 3, pp. 157-180, 2009.

[20] D. Rico, A. B. Martín-Diana, J. M. Barat, and C. Barry-Ryan, "Extending and measuring the quality of fresh-cut fruit and vegetables: a review," Trends in Food Science and Technology, vol. 18, no. 7, pp. 373-386, 2007.

[21] K. R. Aneja, P. Jain, and R. Aneja, A Textbook of Basic and Applied Microbiology, New Age International Publishers, New Delhi, India, 1st edition, 2008.

[22] A. Bevilacqua, M. R. Corbo, and M. Sinigaglia, "Use of natural antimicrobials and high pressure homogenization to control the 
growth of Saccharomyces bayanus in apple juice," Food Control, vol. 24, no. 1-2, pp. 109-115, 2012.

[23] S. Patil, V. P. Valdramidis, B. K. Tiwari, P. J. Cullen, and P. Bourke, "Quantitative assessment of the shelf life of ozonated apple juice," European Food Research and Technology, vol. 232, no. 3, pp. 469-477, 2011.

[24] V. H. Tournas, J. Heeres, and L. Burgess, "Moulds and yeasts in fruit salads and fruit juices," Food Microbiology, vol. 23, no. 7, pp. 684-688, 2006.

[25] K. A. Lawlor, J. D. Schuman, P. G. Simpson, and P. J. Taormina, "Microbiological spoilage of beverages," in Compendium of the Microbiological Spoilage of Foods and Beverages, W. H. Sperber and M. P. Doyle, Eds., Food Microbiology and Food Safety, Springer Science and Business Media, New York, NY, USA, 2009.

[26] C. R. Arias, J. K. Burns, L. M. Friedrich, R. M. Goodrich, and M. E. Parish, "Yeast species associated with orange juice: evaluation of different identification methods," Applied and Environmental Microbiology, vol. 68, no. 4, pp. 1955-1961, 2002.

[27] M. Stratford, "Food and beverage spoilage yeasts," in Yeasts in Food and Beverages Handbook, G. M. Fleet and A. Querol, Eds., Berlin, Germany, pp. 335-379, Springer, 2006.

[28] L. M. Lenovich, R. L. Buchanan, N. J. Worley, and L. Restaino, "Effect of solute on sorbate resitsance in Zygosaccharomyces rouxii," Journal of Food Science, vol. 53, pp. 914-916, 2006.

[29] P. Wareing and R. R. Davenport, "Microbiology of soft drinks and fruit juices," in Chemistry and Technology of Soft Drinks and Fruit Juices, P. R. Ashurst, Ed., Blackwell Publishing, London, UK, 2005.

[30] M. O. Moss, "Fungi, quality and safety issues in fresh fruits and vegetables," Journal of Applied Microbiology, vol. 104, no. 5, pp. 1239-1243, 2008.

[31] N. Delage, A. d'Harlingue, B. Colonna Ceccaldi, and G. Bompeix, "Occurrence of mycotoxins in fruit juices and wine," Food Control, vol. 14, no. 4, pp. 225-227, 2003.

[32] C. M. De Sylos and D. B. Rodriguez-Amaya, "Incidence of patulin in fruits and fruit juices marketed in Campinas, Brazil," Food Additives and Contaminants, vol. 16, no. 2, pp. 71-74, 1999.

[33] F. V. M. Silva and P. Gibbs, "Target selection in designing pasteurization processes for shelf-stable high-acid fruit products," Critical Reviews in Food Science and Nutrition, vol. 44, no. 5, pp. 353-360, 2004.

[34] B. C. M. Salomão, A. P. Slongo, and G. M. F. Aragão, "Heat resistance of Neosartorya fischeri in various juices," Food Science and Technology, vol. 40, no. 4, pp. 676-680, 2007.

[35] J. A. N. Obeta and J. O. Ugwuyani, "Heat resistant fungi in Nigerian fruit juices," International Journal of Food Science and Technology, vol. 30, pp. 587-590, 2007.

[36] M. Voldřich, J. Dobiáš, L. Tichá, M. Čeřovský, and J. Krátká, "Resistance of vegetative cells and ascospores of heat resistant mould Talaromyces avellaneus to the high pressure treatment in apple juice," Journal of Food Engineering, vol. 61, no. 4, pp. 541543, 2004.

[37] R. W. Worbo and D. F. Splistosser, "Microbiology of fruit products," in Processing of Fruit Science and Technology, D. M. Barret, L. P. Somogyi, and H. S. Ramaswamy, Eds., CRC Press, London, U.K, 2004.

[38] I. Walls and R. Chuyate, "Spoilage of fruit juices by Alicyclobacillus acidoterrestris," Food Australia, vol. 52, no. 7, pp. 286-288, 2000 .
[39] M. E. Parish and R. M. Goodrich, "Recovery of presumptive Alicyclobacillus strains from orange fruit surfaces," Journal of Food Protection, vol. 68, no. 10, pp. 2196-2200, 2005.

[40] K. S. Bahçeci and J. Acar, "Modeling the combined effects of $\mathrm{pH}$, temperature and ascorbic acid concentration on the heat resistance of Alicyclobacillus acidoterrestis," International Journal of Food Microbiology, vol. 120, no. 3, pp. 266-273, 2007.

[41] W. H. Groenewald, P. A. Gouws, and R. C. Witthuhn, "Isolation and identification of species of Alicyclobacillus from orchard soil in the Western Cape, South Africa," Extremophiles, vol. 12, no. 1, pp. 159-163, 2008.

[42] W. H. Groenewald, P. A. Gouws, and R. C. Witthuhn, "Isolation, identification and typification of Alicyclobacillus acidoterrestris and Alicyclobacillus acidocaldarius strains from orchard soil and the fruit processing environment in South Africa," Food Microbiology, vol. 26, no. 1, pp. 71-76, 2009.

[43] J. D. Wisotzkey, P. Jurtshuk Jr., G. E. Fox, G. Deinhard, and K. Poralla, "Comparative sequence analyses on the $16 \mathrm{~S}$ rRNA (rDNA) of Bacillus acidocaldarius, Bacillus acidoterrestris, and Bacillus cycloheptanicus and proposal for creation of a new genus, Alicyclobacillus gen. nov," International Journal of Systematic Bacteriology, vol. 42, no. 2, pp. 263-269, 1992.

[44] Y. Smit, M. Cameron, P. Venter, and R. C. Witthuhn, "Alicyclobacillus spoilage and isolation: a review," Food Microbiology, vol. 28, no. 3, pp. 331-349, 2011.

[45] K. Goto, K. Mochida, Y. Kato et al., "Proposal of six species of moderately thermophilic, acidophilic, endospore-forming bacteria: Alicyclobacillus contaminans sp. nov., Alicyclobacillus fastidiosus sp. nov., Alicyclobacillus kakegawensis sp. nov., Alicyclobacillus macrosporangiidus sp. nov., Alicyclobacillus sacchari sp. nov. and Alicyclobacillus shizuokensis sp. nov," International Journal of Systematic and Evolutionary Microbiology, vol. 57, no. 6, pp. 1276-1285, 2007.

[46] R. C. Witthuhn, W. Duvenage, and P. A. Gouws, "Evaluation of different growth media for the recovery of the species of Alicyclobacillus," Letters in Applied Microbiology, vol. 45, no. 2, pp. 224-229, 2007.

[47] S.-S. Chang and D.-H. Kang, "Alicyclobacillus spp. in the fruit juice industry: history, characteristics, and current isolation/detection procedures," Critical Reviews in Microbiology, vol. 30, no. 2, pp. 55-74, 2004.

[48] J. M. Jay, M. J. Loessner, and D. A. Golden, "Extrinsic and intrinsic parameters of food that affect microbial growth," in Modern Food Microbiology, Springer Science; Business Media Incorporation, New York, NY, USA, 2005.

[49] M. Z. Durak, J. J. Churey, M. D. Danyluk, and R. W. Worobo, "Identification and haplotype distribution of Alicyclobacillus spp. from different juices and beverages," International Journal of Food Microbiology, vol. 142, no. 3, pp. 286-291, 2010.

[50] M. D. Danyluk, L. M. Friedrich, C. Jouquand, R. GoodrichSchneider, M. E. Parish, and R. Rouseff, "Prevalence, concentration, spoilage, and mitigation of Alicyclobacillus spp. in tropical and subtropical fruit juice concentrates," Food Microbiology, vol. 28, no. 3, pp. 472-477, 2011.

[51] R. C. Witthuhn, Y. Smit, M. Cameron, and P. Venter, "Guaiacol production by Alicyclobacillus and comparison of two guaiacol detection methods," Food Control, vol. 30, no. 2, pp. 700-704, 2013.

[52] K. Kusano, H. Yamada, M. Niwa, and K. Yamasato, "Propionibacterium cyclohexanicum sp. nov., a new acid-tolerant $\omega$-cyclohexyl fatty acid-containing Propionibacterium isolated 
from spoiled orange juice," International Journal of Systematic Bacteriology, vol. 47, no. 3, pp. 825-831, 1997.

[53] B. Siegmund and B. Pöllinger-Zierler, "Growth behavior of off-flavor-forming microorganisms in apple juice," Journal of Agricultural and Food Chemistry, vol. 55, no. 16, pp. 6692-6699, 2007.

[54] M. Stratford, P. D. Holman, and M. B. Cole, "Fruit juices, fruit drinks and soft drinks," in Microbiological Safety and Quality of Food, B. lund, A. C. Baird Parker, and W. G. Grahame, Eds., ASPEN, Gaithersburg, Md, USA, 2000.

[55] H. Daryaei and V. M. Balasubramaniam, "Kinetics of Bacillus coagulans spore inactivation in tomato juice by combined pressure-heat treatment," Food Control, vol. 30, no. 1, pp. 168$175,2013$.

[56] FDA (U.S. Food and Drug Administration), "Federal register proposed rules-63 FR 20449 April 24, (1998). HACCP; procedures for the safe and sanitary processingand importing of juice; food labeling : warning notice statements; labeling of juice products," Federal Register, vol. 63, pp. 20449-20486, 1998, http://www.fda.gov/Food/FoodSafety/ HazardAnalysisCriticalControlPointsHACCP/JuiceHACCP/ ucm082031.htm.

[57] I. Van Opstal, C. F. Bagamboula, T. Theys, S. C. M. Vanmuysen, and C. W. Michiels, "Inactivation of Escherichia coli and Shigella in acidic fruit and vegetable juices by peroxidase systems," Journal of Applied Microbiology, vol. 101, no. 1, pp. 242-250, 2006.

[58] J. E. Lewis, P. Thompson, B. Rao, C. Kalavati, and B. Rajanna, "Human Bacteria in street vended fruit juices: a case study of Vishakhapatnam city, India," Internet Journal of Food Safety, vol. 8, pp. 35-38, 2006.

[59] D. P. Mahale, R. G. Khade, and K. V. Vaidya, "Microbiological Analysis of Street vended Fruit juices From Mumbai city, India," Internet Journal of Food Safety, vol. 10, pp. 31-34, 2008.

[60] T. Ketema, T. Gadissa, and K. Bacha, "Microbiological safety of fruit juices served in cafes/restaurants, Jimma town, South west, Ethopia," Ethiopian Journal of Health Science, vol. 18, pp. 95-100, 2008.

[61] A. Titarmare, P. Dabholkar, and S. Godbole, "Bacteriological analysis of street vended fresh fruit and vegetable juices in Nagpur city, India," Internet Journal of Food Safety, vol. 11, pp. $1-3,2009$.

[62] D. H. Tambeker, V. J. Jaiswal, D. V. Dhanorker, P. B. Gulhane, and M. N. Dudhane, "Microbial quality and safety of street vended fruit juices: a case study of Amravati city," Internet Journal of Food Safety, vol. 10, pp. 72-76, 2009.

[63] CDC, Annual Listing of Food Borne Disease Outbreaks, United States, 1990-2004, CDC, Atlanta, Ga, USA, 2007.

[64] I. van Opstal, C. F. Bagamboula, T. Theys, S. C. M. Vanmuysen, and C. W. Michiels, "Inactivation of Escherichia coli and Shigella in acidic fruit and vegetable juices by peroxidase systems," Journal of Applied Microbiology, vol. 101, no. 1, pp. 242-250, 2006.

[65] CDC, "Outbreaks of Salmonella serotype Muenchen infections associated with unpasteurized orange juice-United State and Canada," Morbidity and Mortality Weekly Report, vol. 48, pp. 582-585, 1999.

[66] G. Krause, R. Terzagian, and R. Hammond, "Outbreak of Salmonella serotype anatum infection associated with unpasteurized orange juice," Southern Medical Journal, vol. 94, no. 12, pp. 1168-1172, 2001.
[67] CDC, "Foodborne Outbreak Online Database (FOOD)," 2011, http://wwwn.cdc.gov/foodborneoutbreaks/default.aspx.

[68] CDC, "Outbreaks of Escherichia coli O157:H7 infection and cryptosporidiosis associated with drinking unpasteurized apple cider-connecticut and New York, October 1996," Morbidity and Mortality Weekly Report, vol. 46, pp. 4-8, 1997.

[69] S. H. Cody, M. K. Glynn, J. A. Farrar et al., "An outbreak of Escherichia coli O157:H7 infection from unpasteurized commercial apple juice," Annals of Internal Medicine, vol. 130, no. 3, pp. 202-209, 1999.

[70] FDA, "Federal register final rule- 66Fr 6137, January 19, 2001: hazard analysis and critical control point (HACCP); procedures for the safe and sanitary processing and importing of juices," Federal Register, vol. 66, no. 13, pp. 6137-6202, 2001.

[71] K. R. Aneja, Experiments in Microbiology, Plant Pathology and Biotechnology, New Age International Publishers, New Delhi, India, 4th edition, 2003.

[72] R. A. Samson, E. S. Hoekstra, and J. S. Frisvad, Introduction to Food and Airborne Fungi, Ponson and Looyen, Wageningen, The Netherlands, 7th edition, 2004.

[73] W. B. Whitman, M. Goodfellow, P. Kämpfer et al., Bergey's Manual of Systematic Bacteriology, vol. 5, 2012.

[74] A. S. Kutama, I. Yusuf, and M. Hayatu, "Detection of heat resistant molds in some canned fruit juices sold in Kano, Nigeria," Bioscience Research Communications, vol. 22, pp. 221225, 2009.

[75] A. M. McKay, M. Linton, J. Stirling, A. Mackle, and M. F. Patterson, "A comparative study of changes in the microbiota of apple juice treated by high hydrostatic pressure (HHP) or high pressure homogenisation (HPH)," Food Microbiology, vol. 28, no. 8, pp. 1426-1431, 2011.

[76] A. Vercammen, B. Vivijs, I. Lurquin, and C. W. Michiels, "Germination and inactivation of Bacillus coagulans and Alicyclobacillus acidoterrestris spores by high hydrostatic pressure treatment in buffer and tomato sauce," International Journal of Food Microbiology, vol. 152, no. 3, pp. 162-167, 2012.

[77] A. V. Charles-Rodríguez, G. V. Nevárez-Moorillón, Q. H. Zhang, and E. Ortega-Rivas, "Comparison of thermal processing and pulsed electric fields treatment in pasteurization of apple juice," Food and Bioproducts Processing, vol. 85, no. 2, pp. 93-97, 2007.

[78] Z. Cserhalmi, Á. Sass-Kiss, M. Tóth-Markus, and N. Lechner, "Study of pulsed electric field treated citrus juices," Innovative Food Science and Emerging Technologies, vol. 7, no. 1-2, pp. 49$54,2006$.

[79] J. B. Gurtler, R. B. Bailey, D. J. Geveke, and H. Q. Zhang, "Pulsed electric field inactivation of E. coli O157:H7 and non-pathogenic surrogate E. coli in strawberry juice as influenced by sodium benzoate, potassium sorbate, and citric acid," Food Control, vol. 22, no. 10, pp. 1689-1694, 2011.

[80] S. L. Chia, S. Rosnah, M. A. Noranizan, and W. D. Wan Ramli, "The effect of storage on the quality attributes of ultravioletirradiated and thermally pasteurised pineapple juices," International Food Research Journal, vol. 19, no. 3, pp. 1001-1010, 2012.

[81] M. Keyser, I. A. Muller, F. P. Cilliers, W. Nel, and P. A. Gouws, "Ultraviolet radiation as a non-thermal treatment for the inactivation of microorganisms in fruit juice," Innovative Food Science and Emerging Technologies, vol. 9, no. 3, pp. 348354, 2008.

[82] B. K. Tiwari, C. P. O'Donnell, and P. J. Cullen, "Effect of non thermal processing technologies on the anthocyanin content of 
fruit juices," Trends in Food Science and Technology, vol. 20, no. 3-4, pp. 137-145, 2009.

[83] C. D. Char, E. Mitilinaki, S. N. Guerrero, and S. M. Alzamora, "Use of high-intensity ultrasound and UV-C light to inactivate some microorganisms in fruit juices," Food and Bioprocess Technology, vol. 3, no. 6, pp. 797-803, 2010.

[84] A. I. V. Ross, M. W. Griffiths, G. S. Mittal, and H. C. Deeth, "Combining nonthermal technologies to control foodborne microorganisms," International Journal of Food Microbiology, vol. 89, no. 2-3, pp. 125-138, 2003.

[85] V. Touch, S. Hayakawa, S. Yamada, and S. Kaneko, "Effects of a lactoperoxidase-thiocyanate-hydrogen peroxide system on Salmonella enteritidis in animal or vegetable foods," International Journal of Food Microbiology, vol. 93, no. 2, pp. 175-183, 2004.

[86] M. M. Tajkarimi, S. A. Ibrahim, and D. O. Cliver, "Antimicrobial herb and spice compounds in food," Food Control, vol. 21, no. 9, pp. 1199-1218, 2010.

[87] P. Skandamis, K. Koutsoumanis, K. Fasseas, and G.-J. E. Nychas, "Inhibition of oregano essential oil and edta on Escherichia coli O157:H7," Italian Journal of Food Science, vol. 13, no. 1, pp. 65-75, 2001.

[88] C. F. Carson, B. J. Mee, and T. V. Riley, "Mechanism of action of Melaleuca alternifolia (tea tree) oil on Staphylococcus aureus determined by time-kill, lysis, leakage, and salt tolerance assays and electron microscopy," Antimicrobial Agents and Chemotherapy, vol. 46, no. 6, pp. 1914-1920, 2002.

[89] S. Burt, "Essential oils: their antibacterial properties and potential applications in foods-a review," International Journal of Food Microbiology, vol. 94, no. 3, pp. 223-253, 2004.

[90] E. Piecková and R. A. Samson, "Heat resistance of Paecilomyces variotii in sauce and juice," Journal of Industrial Microbiology and Biotechnology, vol. 24, no. 4, pp. 227-230, 2000.

[91] R. E. Besser, S. M. Lett, J. T. Weber et al., "An outbreak of diarrhea and hemolytic uremic syndrome from Escherichia coli O157:H7 in fresh-pressed apple cider," Journal of the American Medical Association, vol. 269, no. 17, pp. 2217-2220, 1993.

[92] B. R. Singh, S. B. Kulshreshtha, and K. N. Kapoor, "Orange juice-borne diarrhoeal outbreak due to Enterotoxigenic E.coli," Journal of Food Science and Technology, vol. 32, no. 6, pp. 504506, 1995.

[93] P. S. Millard, K. F. Gensheimer, D. G. Addiss et al., "An outbreak of cryptosporidiosis from fresh-pressed apple cider," Journal of the American Medical Association, vol. 272, no. 20, pp. 15921596, 1994.

[94] J. C. Buzby and S. R. Crutchfield, "New Juice Regulations Underway. Food Review," 1999, http://www.fda.gov/Food/ FoodSafety/HazardAnalysisCriticalControlPointsHACCP/ JuiceHACCP/ucm082031.htm.

[95] CDC, "Outbreak of Salmonella Hartford infections among travelers to Orlando, Florida," EPI-AID Trip Report, pp. 95-162, 1995.

[96] K. A. Cook, T. E. Dobbs, W. G. Hlady et al., "Outbreak of Salmonella serotype Hartford infections associated with unpasteurized orange juice," Journal of the American Medical Association, vol. 280, no. 17, pp. 1504-1509, 1998.

[97] M. Parish, "Relevancy of Salmonella and pathogenic E.coli to fruit juices," in Proceedings of the IFU-Workshop "Microbiology", Fruit Processing, vol. 10, pp. 246-250, 2000.

[98] H. Thurston, J. Stuart, B. McDonnell, S. Nicholas, and T. Cheasty, "Fresh orange juice implicated in an outbreak of
Shigella flexneri among visitors to a South African game reserve," Journal of Infection, vol. 36, no. 3, p. 350, 1998.

[99] CDC, "Outbreak of Escherichia coli O157:H7 infections associated with drinking unpasteurized commercial apple juiceBritish Columbia, California, Colorado and Washington. October 1996," Morbidity and Mortality Weekly Report, vol. 45, p. 975, 1996.

[100] S. Tamblyn, J. deGrosbois, D. Taylor, and J. Stratton, "An outbreak of Escherichia coli O157:H7 infection associated with unpasteurized non-commercial, custom-pressed apple ciderontario, 1998," Canada Communicable Disease Report, vol. 25, no. 13, pp. 113-120, 1999.

[101] M. E. Butler, "Salmonella outbreak leads to juice recall in Western states," Food Chemical News, 2000.

[102] J. D. Vojdani, L. R. Beuchat, and R. V. Tauxe, "Juice-associated outbreaks of human illness in the United States, 1995 through 2005, Journal of Food Protection, vol. 71, no. 2, pp. 356-364, 2008.

[103] S. Jain, S. A. Bidol, J. L. Austin et al., "Multistate outbreak of Salmonella Typhimurium and Saintpaul infections associated with unpasteurized orange juice-United States, 2005," Clinical Infectious Diseases, vol. 48, no. 8, pp. 1065-1071, 2009.

[104] K. S. Pereira, F. L. Schmidt, A. M. A. Guaraldo, R. M. B. Franco, V. L. Dias, and L. A. C. Passos, "Chagas' disease as a foodborne illness," Journal of Food Protection, vol. 72, no. 2, pp. 441-446, 2009.

[105] CDC, "Botulism associated with commercial carrot juiceGeorgia and Florida," Morbidity and Mortality Weekly Report, vol. 55, pp. 1098-1099, 2006.

[106] FDA, "DHMH Issues Consumer Alert Regarding Recall of Baugher's Apple Cider," http://www.fda.gov/Safety/Recalls/ ucm232878.htm.

[107] M. Linton, J. M. J. McClements, and M. F. Patterson, "Inactivation of Escherichia coli O157:H7 in orange juice using a combination of high pressure and mild heat," Journal of Food Protection, vol. 62, no. 3, pp. 277-279, 1999.

[108] H. S. Ramaswamy, E. Riahi, and E. Idziak, "High-pressure destruction kinetics of E. coli (29055) in apple juice," Journal of Food Science, vol. 68, no. 5, pp. 1750-1756, 2003.

[109] A. Bayindirli, H. Alpas, F. Bozoglu, and M. Hizal, "Efficiency of high pressure treatment on inactivation of pathogenic microorganisms and enzymes in apple, orange, apricot and sour cherry juices," Food Control, vol. 17, no. 1, pp. 52-58, 2006.

[110] Avure Technologies, http://www.avure.com.

[111] J. A. Guerrero-Beltran, G. V. Barbosa-Canovas, and J. WeltiChanes, "High hydrostatic pressure effect on natural microflora, Saccharomyces cerevisiae, Escherichia coli, and Listeria Innocua in navel orange juice," International Journal of Food Engineering, vol. 7, no. 1, article 14, 2011.

[112] W. J. Briñez, A. X. Roig-Sagués, M. M. H. Herrero, and B. G. López, "Inactivation by ultrahigh-pressure homogenization of Escherichia coli strains inoculated into orange juice," Journal of Food Protection, vol. 69, no. 5, pp. 984-989, 2006.

[113] F. P. Campos and M. Cristianini, "Inactivation of Saccharomyces cerevisiae and Lactobacillus plantarum in orange juice using ultra high-pressure homogenisation," Innovative Food Science and Emerging Technologies, vol. 8, no. 2, pp. 226-229, 2007.

[114] A. M. McKay, "Inactivation of fungal spores in apple juice by high pressure homogenization," Journal of Food Protection, vol. 72, no. 12, pp. 2561-2564, 2009. 
[115] F. Patrignani, L. Vannini, S. L. S. Kamdem, R. Lanciotti, and M. E. Guerzoni, "Effect of high pressure homogenization on Saccharomyces cerevisiae inactivation and physico-chemical features in apricot and carrot juices," International Journal of Food Microbiology, vol. 136, no. 1, pp. 26-31, 2009.

[116] F. Patrignani, L. Vannini, S. L. S. Kamdem, R. Lanciotti, and M. E. Guerzoni, "Potentialities of high pressure homogenization to inactivate Zygosaccharomyces bailli in fruit juices," Journal of Food Science, vol. 75, no. 2, pp. M116-M120, 2010.

[117] G. A. Evrendilek, Q. H. Zhang, and E. R. Richter, "Inactivation of Escherichia coli O157:H7 and Escherichia coli 8739 in apple juice by pulsed electric fields," Journal of Food Protection, vol. 62, no. 7, pp. 793-796, 1999.

[118] Z. T. Jin and Q. H. Zhang, "Pulsed electric field inactivation of microorganisms and preservation of quality of cranberry juice," Journal of Food Processing and Preservation, vol. 23, no. 6, pp. 481-497, 1999.

[119] G. A. Evrendilek, Z. T. Jin, K. T. Ruhlman, X. Qiu, Q. H. Zhang, and E. R. Richter, "Microbial safety and shelf-life of apple juice and cider processed by bench and pilot scale PEF systems," Innovative Food Science and Emerging Technologies, vol. 1, no. 1, pp. 77-86, 2000.

[120] C. J. McDonald, S. W. Lloyd, M. A. Vitale, K. Petersson, and F. Innings, "Effects of pulsed electric fields on microorganisms in orange juice using electric field strengths of 30 and $50 \mathrm{kV} / \mathrm{cm}$," Journal of Food Science, vol. 65, no. 6, pp. 984-989, 2000.

[121] J. Iu, G. S. Mittal, and M. W. Griffiths, "Reduction in levels of Escherichia coli O157:H7 in apple cider by pulsed electric fields," Journal of Food Protection, vol. 64, no. 7, pp. 964-969, 2001.

[122] Z. Liang, G. S. Mittal, and M. W. Griffiths, "Inactivation of Salmonella typhimurium in orange juice containing antimicrobial agents by pulsed electric field," Journal of Food Protection, vol. 65, no. 7, pp. 1081-1087, 2002.

[123] V. Heinz, S. Toepfl, and D. Knorr, "Impact of temperature on lethality and energy efficiency of apple juice pasteurization by pulsed electric fields treatment," Innovative Food Science and Emerging Technologies, vol. 4, no. 2, pp. 167-175, 2003.

[124] P. Elez-Martínez, J. Escolà-Hernández, R. C. Soliva-Fortuny, and O. Martín-Belloso, "Inactivation of Lactobacillus brevis in orange juice by high-intensity pulsed electric fields," Food Microbiology, vol. 22, no. 4, pp. 311-319, 2005.

[125] F. Sampedro, A. Rivas, D. Rodrigo, A. Martínez, and M. Rodrigo, "Pulsed electric fields inactivation of Lactobacillus plantarum in an orange juice-milk based beverage: effect of process parameters," Journal of Food Engineering, vol. 80, no. 3, pp. 931-938, 2007.

[126] G. A. Evrendilek, F. M. Tok, E. M. Soylu, and S. Soylu, "Inactivation of Penicillum expansum in sour cherry juice, peach and apricot nectars by pulsed electric fields," Food Microbiology, vol. 25, no. 5, pp. 662-667, 2008.

[127] T. Koutchma, S. Keller, S. Chirtel, and B. Parisi, "Ultraviolet disinfection of juice products in laminar and turbulent flow reactors," Innovative Food Science and Emerging Technologies, vol. 5, no. 2, pp. 179-189, 2004.

[128] M. T. Tran and M. Farid, "Ultraviolet treatment of orange juice," Innovative Food Science \& Emerging Technologies, vol. 5, no. 4, pp. 495-502, 2004.

[129] J. A. Guerrero-Beltrán and G. V. Barbosa-Cánovas, "Reduction of Saccharomyces cerevisiae, Escherichia coli and Listeria innocua in apple juice by ultraviolet light," Journal of Food Process Engineering, vol. 28, no. 5, pp. 437-452, 2005.
[130] M. Zenker, V. Heinz, and D. Knorr, "Application of ultrasoundassisted thermal processing for preservation and quality retention of liquid foods," Journal of Food Protection, vol. 66, no. 9, pp. 1642-1649, 2003.

[131] M. Valero, N. Recrosio, D. Saura, N. Muñoz, N. Martí, and V. Lizama, "Effects of ultrasonic treatments in orange juice processing," Journal of Food Engineering, vol. 80, no. 2, pp. 509516, 2007.

[132] Y. Yuan, Y. Hu, T. Yue, T. Chen, and Y. M. Lo, "Effect of ultrasonic treatments on thermoacidophilic Alicyclobacillus acidoterrestris in apple juice," Journal of Food Processing and Preservation, vol. 33, no. 3, pp. 370-383, 2009.

[133] V. M. Gómez-López, L. Orsolani, A. Martínez-Yépez, and M. S. Tapia, "Microbiological and sensory quality of sonicated calcium-added orange juice," LWT: Food Science and Technology, vol. 43, no. 5, pp. 808-813, 2010.

[134] S. Roller and N. Covill, "The antifungal properties of chitosan in laboratory media and apple juice," International Journal of Food Microbiology, vol. 47, no. 1-2, pp. 67-77, 1999.

[135] G. Kisko, R. Sharp, and S. Roller, "Chitosan inactivates spoilage yeasts but enhances survival of Escherichia coli O157:H7 in apple juice," Journal of Applied Microbiology, vol. 98, no. 4, pp. 872880, 2005.

[136] J. Yuste and D. Y. C. Fung, "Inactivation of Listeria monocytogenes Scott A 49594 in apple juice supplemented with cinnamon," Journal of Food Protection, vol. 65, no. 10, pp. 16631666, 2002.

[137] R. M. Raybaudi-Massilia, J. Mosqueda-Melgar, and O. MartínBelloso, "Antimicrobial activity of essential oils on Salmonella enteritidis, Escherichia coli, and Listeria innocua in fruit juices," Journal of Food Protection, vol. 69, no. 7, pp. 1579-1586, 2006.

[138] M. Friedman, P. R. Henika, C. E. Levin, and R. E. Mandrell, "Antibacterial activities of plant essential oils and their components against Escherichia coli O157:H7 and Salmonella enterica in apple juice," Journal of Agricultural and Food Chemistry, vol. 52, no. 19, pp. 6042-6048, 2004.

[139] P. Nguyen and G. S. Mittal, "Inactivation of naturally occurring microorganisms in tomato juice using pulsed electric field (PEF) with and without antimicrobials," Chemical Engineering and Processing: Process Intensification, vol. 46, no. 4, pp. 360365, 2007.

[140] S. Ferrante, S. Guerrero, and S. M. Alzamora, "Combined use of ultrasound and natural antimicrobials to inactivate Listeria monocytogenes in orange juice," Journal of Food Protection, vol. 70, no. 8, pp. 1850-1856, 2007.

[141] A. M. Hodgins, G. S. Mittal, and M. W. Griffiths, "Pasteurization of fresh orange juice using low-energy pulsed electrical field," Journal of Food Science, vol. 67, no. 6, pp. 2294-2299, 2002.

[142] P. Pathanibul, T. M. Taylor, P. M. Davidson, and F. Harte, "Inactivation of Escherichia coli and Listeria innocua in apple and carrot juices using high pressure homogenization and nisin," International Journal of Food Microbiology, vol. 129, no. 3, pp. 316-320, 2009. 

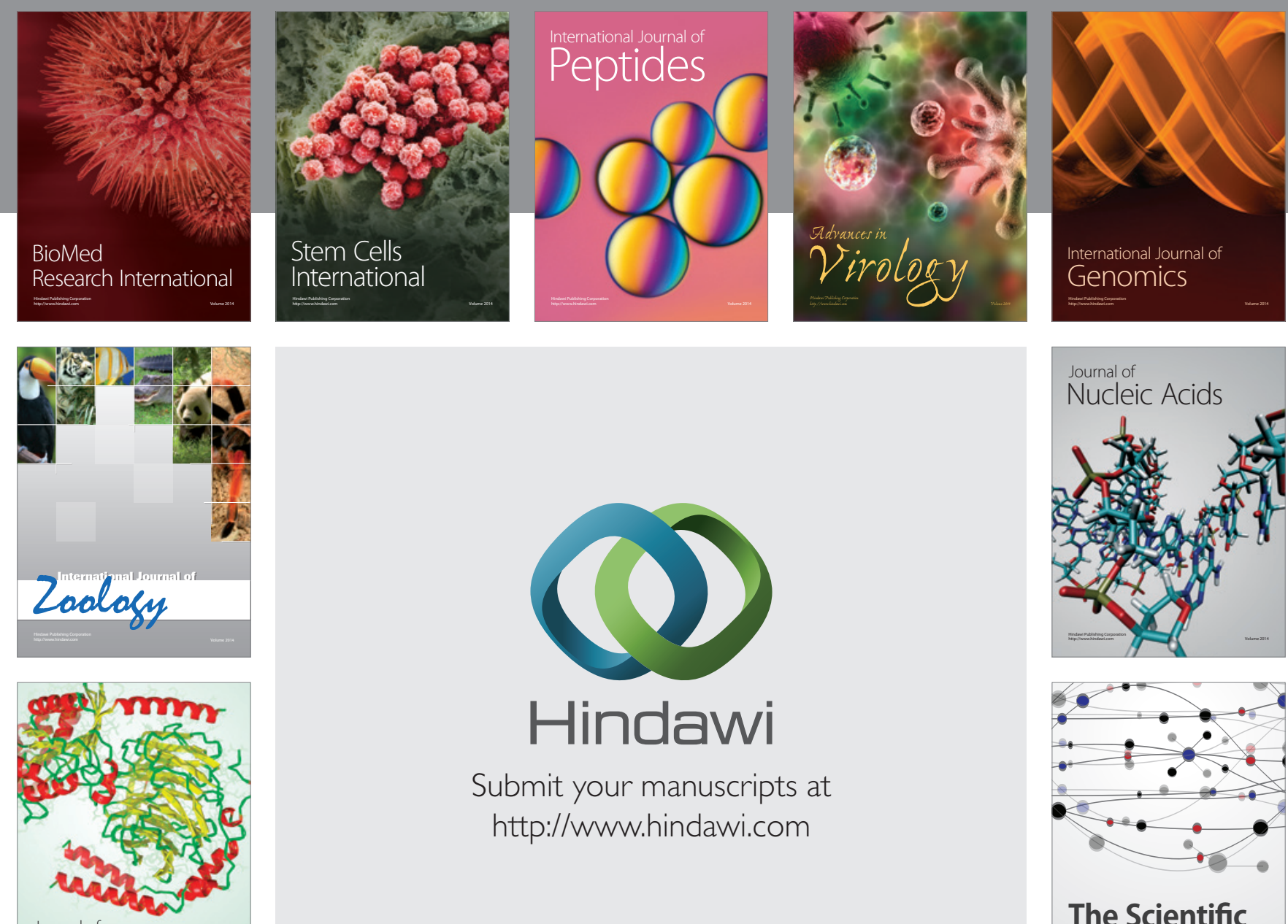

Submit your manuscripts at

http://www.hindawi.com

Journal of
Signal Transduction
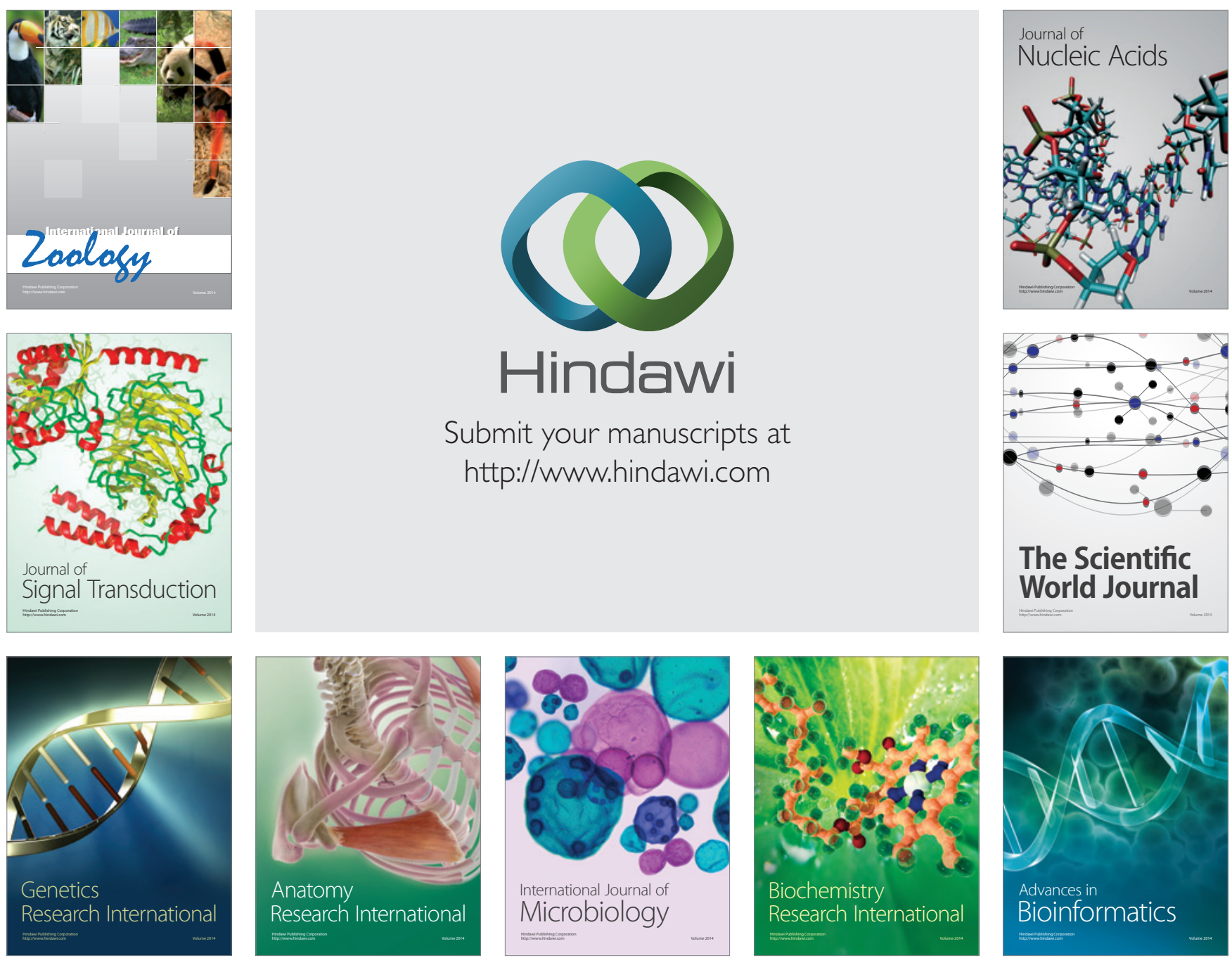

The Scientific World Journal
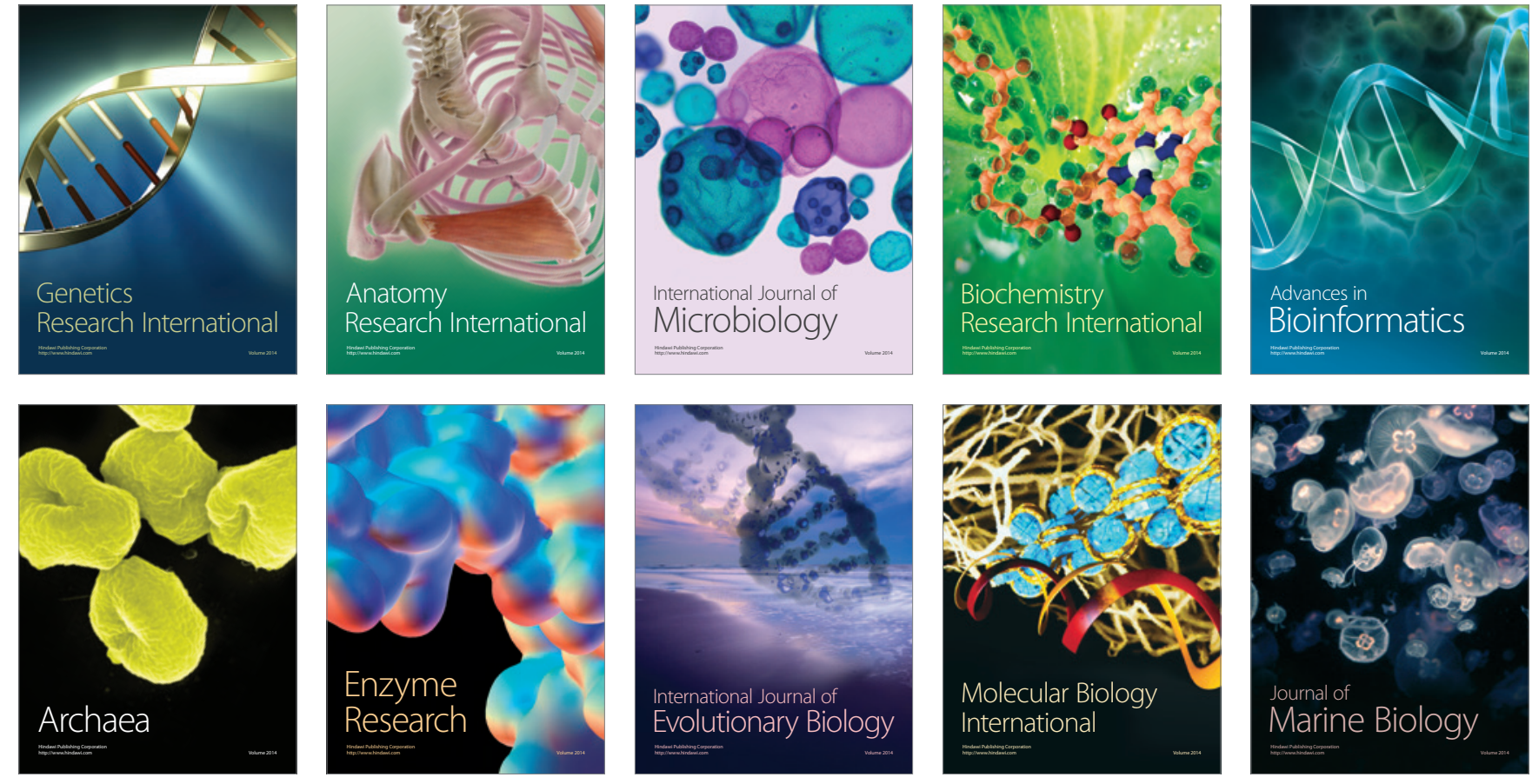